\title{
Aktivitas Antibakteri Ekstrak Metanol Daun Turi (Sesbania grandiflora L.) Terhadap Pertumbuhan Klebsiella pneumoniae
}

\author{
Huurun Iien ${ }^{1 *}$, Lalu Zulkifli ${ }^{1,2}$, Prapti Sedijani, \\ ${ }^{1}$ Program Studi Magister Pendidikan IPA Universitas Mataram, Mataram, Indonesia \\ ${ }^{2}$ Program Studi Pendidikan Biologi FKIP Universitas Mataram, Mataram, Indonesia
}

\section{Riwayat artikel}

Received : 06 April 2020

Revised : 20 April 2020

Accepted : 02 Juni 2020

Published : 06 Juni 2020

*Corresponding Author: Huurun Iien,

Program Studi Magister Pendidikan IPA Universitas

Mataram, Mataram, Indonesia Email:

huurun_iien@yahoo.co.id

\begin{abstract}
Abstrak: Sesbania grandiflora (tanaman turi) memiliki berbagai khasiat dalam pengobatan penyakit termasuk yang dapat digunakan sebagai campuran dalam persiapan bahan antibakteri. Tumbuhan ini mengandung senyawa metabolit sekunder yang dapat memiliki aktivitas sebagai zat antibakateri. Penelitian ini bertujuan untuk mengetahui kandungan metabolit sekunder ekstrak methanol daun turi dan mengetahui bioaktivitas ekstrak tersebut terhadap pertumbuhan bakteri Klebsiella pneumoniae. Daun S. grandiflora diekstraksi dengan metode maserasi menggunakan pelarut metanol. Hasil uji fitokimia secara kualitatif menunjukkan bahwa ekstrak metanol daun turi mengandung senyawa metabolit sekunder seperti tannin, saponin, dan terpenoid. Uji penghambatan sifat antibakteri dilakukan berdasarkan metode difusi sumuran, dengan mengukur rata-rata zona hambat yang terbentuk pada media MHA. Hasil penelitian menunjukkan bahwa ekstrak metanol dari daun $S$. grandiflora dengan konsentrasi $10 \%, 25 \%, 40 \%$, dan $55 \%$ menunjukkan diameter rata-rata zona hambatan masing-masing 7,2, 14,4, 17,9, dan 22,5 mm. Kemampuan untuk menghambat pertumbuhan bakteri pada konsentrasi 55\%, 40\%, dan $25 \%$ dikategorikan sebagai penghambatan kuat karena memiliki diameter zona hambat rata-rata lebih dari $12 \mathrm{~mm}$ (sesuai dengan kategori Vasanthakumari). Konsentrasi yang semakin tinggi memberikan efek penghambatan yang lebih kuat. Hasil di atas menunjukkan bahwa kandungan ekstrak daun tanaman turi dapat digunakan sebagai sumber bahan obat baru di masa depan melalui penelitian lebih lanjut.
\end{abstract}

Kata kunci: Ekstrak Daun Turi, maserasi, antibakteri, Klebsiella pneumoniae, metabolit sekunder

Abstract: Sesbania grandiflora (Turi plant) has various medicinal properties, including as a mixture in the preparation of antibacterial ingredients. This plant contains secondary metabolites that can have antibacterial activity. This study aims to determine the secondary metabolite content of the turi leaf methanol extract and determine the bioactivity of the extract on the growth of Klebsiella pneumoniae. S. grandiflora leaves were extracted using the maceration method using methanol as a solvent. Phytochemical test results show that the turi leaf methanol extract contains secondary metabolites such as tannin, saponin, and terpenoids. The antibacterial inhibition test was carried out based on the well diffusion method, by measuring the average of the zone of inhibition formed on the MHA media. The results showed that the methanol extract of the leaves of $S$. grandiflora with concentrations of $10 \%, 25 \%, 40 \%$, and $55 \%$ showed an average diameter of inhibition zones 7.2, 14.4, 17.9, and 22, $5 \mathrm{~mm}$, respectively. The ability to inhibit bacterial growth at concentrations of 55\%, 40\%, and $25 \%$ were categorized as having a strong inhibitory power because it has an average inhibition zone diameter of more than $12 \mathrm{~mm}$ (according to the Vasanthakumari category). The higher concentration gives a stronger inhibitory effect. The above results show that the leaf of the turi plant can be used as a source of new medicinal ingredients in the future.

Keywords: Turi Leaf Extract, maceration, antimicrobial, Klebsiella pneumoniae, secondary metabolites 


\section{Pendahuluan}

Indonesia adalah negara agraris yang memiliki areal pertanian dan perkebunan yang luas serta pekarangan yang dapat ditanami tumbuhan obat (Lestari, 2016). Sejak dahulu tumbuhan sudah digunakan sebagai obat tradisional. Mengingat bahwa biaya pengobatan yang tidak dapat dijangkau oleh semua orang, maka tumbuhan obat merupakan salah satu alternatif yang terjangkau bagi masyarakat (Bangun, 2012)

Tumbuhan memiliki banyak peranan yang penting dalam kehidupan manusia, seperti penggunaan pada pengobatan secara tradisional. Ramuan tradisional sebagian besar berasal dari tumbuhan, baik dari akar, kayu, daun, bunga kulit batang, ataupun bijinya. Pengobatan secara tradisional memerlukan riset ilmiah untuk dapat dipertanggung jawabkan, seperti penelitian toksikologi, farmakologi, dan identifikasi serta isolasi senyawa kimia aktif yang terdapat dalam tumbuhan. Tumbuhan obat dapat digunakan sebagai antibakteri pada beberapa jenis penyakit. Indonesia yang memiliki iklim tropis terdapat beberapa jenis penyakit yang disebabkan oleh bakteri patogen dan cukup banyak diderita oleh masyarakat (Sjoekoer et al., 2013). Salah satu tumbuhan yang memiliki potensi sebagai antimikroba terhadap patogen adalah tanaman Turi (Sesbania grandiflora).

Potensi lain tanaman turi, selain sebagai sayursayuran dan pakan ternak adalah kandungan metabolit sekunder yakni tanin dan flavonoid (Panda et al. 2013). Selain itu, kandungam lainya adalah flavonoid yang merupakan komponen penting yang terdapat pada bunga turi dan berperan dalam aktivitas penghambatan antibakter (Arunabha dan Satish, 2015). Sementara itu, turi juga mengandung tanin dan beberapa nutrisi serta astringent alami (Vinothini et al. 2017). Daun turi berdasarkan hasil uji fitokimia memiliki sifat antixiolitik dan antikonvulsan (Avalaskar et al. 2011). Amaranti (2017) membuktikan bahwa tumbuhan turi memiliki kandungan saponin pada organ daun, tangkai dan biji dengan kadar tertinggi terdapat pada organ daun dan terendah pada organ biji.

Salah satu jenis mikroba patogen adalah Klebsiella pneumoniae. K. pneumoniae merupakan bakteri gram negatif (-), berbentuk batang pendek, memiliki ukuran 0,5-0,5 x 1,2 $\mu$. Bakteri ini memiliki kapsul, tetapi tidak membentuk spora. K. pneumoniae tidak mampu bergerak karena tidak memiliki flagel tetapi mampu memfermentasikan karbohidrat membentuk asam dan gas. Berdasarkan kebutuhannya akan oksigen, Klebsiella pneumoniae merupakan bakteri fakultatif anaerob. Klebsiella pneumoniae dapat memfermentasikan laktosa. Spesies $K$. pneumoniae menunjukkan pertumbuhan mucoid, kapsul polisakarida yang besar dan tidak motil (Anderson et al. 2007).
Bakteri jenis $K$. pneumoniae dapat menyebabkan pneumoniae, yang menyerang jaringan paru-paru (alveoli). $K$. pneumoniae yang menyebabkan penyakit paru-paru memberikan penampakan berupa pembengkakan paru-paru sehingga lobus kiri dan kanan paru-paru menjadi tidak sama, demam (panas-dingin), batuk-batuk (bronkhitis), penebalan dinding mukosa dan dahak berdarah. Selain itu, bakteri ini juga dapat menyebabkan infeksi saluran kemih, dan infeksi nosokomial (Beesley et al. 1983). K. pneumoniae menduduki ranking kedua setelah Escherichia coli untuk infeksi saluran kemih di manusia (Sarathbabu et al. 2012).

Berkaitan dengan potensi tumbuhan turi yang memiliki kandungan metabolit sekunder sebagai bahan untuk menghambat pertumbuhan bakteri patogen dan kebutuhan medis dalam menyediakan bahan baku. Oleh karena itu, perlu dilakukan penelitian tentang kemampuan dan potensi ekstrak daun turi sebagai antibakteri pada bakteri patogen $K$. pneumoniae.

Tujuan penelitian ini adalah untuk mendeterminasi dan menentukan aktivitas antibakteri ekstrak metanol daun turi pada pertumbuhan bakteri $K$. pneumoniae berdasarkan diameter zona hambat.

\section{Bahan dan Metode}

Penelitian ini dilakukan pada bulan FebruariMaret 2019 di laboratorium Mikrobiologi Program Studi Pendidikan Biologi Fakultas Keguruan dan Ilmu Pendidikan Universitas Mataram.

Alat yang digunakan dalam penelitian yaitu autoclave, timbangan analitik, blender, gelas ukur, tabung reaksi, erlenmeyer, beker gelas, corong, hot plate, kertas milimeter blok, batang pengaduk, cawan petri, jarum ose, pingset, mikropipet, laminar air flaw, inkubator.

Bahan yang diperlukan adalah daun turi putih sebanyak $5 \mathrm{~kg}$, bakteri Klebsiella pneumoniae, Nutrien Agar (NA), Muller Hilton Agar (MHA), ciprofloxaxin, metanol, aquades, $\mathrm{NaCl}$, kertas saring, aluminium foil, kertas lebel dan spritus.

Jenis penelitian ini merupakan eksperimental laboratorium dengan sampel ekstrak metanol daun turi putih yang dibuat dengan empat variasi konsentrasi $10 \%, 25 \%, 40 \%, 55 \%$ dan dilakukan pengujian pada bakteri uji $K$. pneumoniae.

\section{Sampel}

Pada tahap awal sampel daun turi ditimbang dengan berat $5 \mathrm{~kg}$. Selanjutnya dicuci dengan air mengalir dengan tujuan menghilangkan pengotor. Sampel kemudian dirajang untuk mempermudah proses pengeringan. Pengeringan sampel dilakukan dengan cara diangin-anginkan selama 2 minggu. Sampel yang sudah kering kemudian di blender hingga menjadi serbuk dan ditimbang. Serbuk yang 
dihasilkan diayak dengan ayakan mesh, hingga diperoleh serbuk halus.

\section{Pembuatan Ekstrak}

Metode yang digunakan untuk mengekstrak daun turi ( $S$. grandiflora) yaitu dengan menggunakan metode maserasi. Ditimbang sebanyak $600 \mathrm{~g}$, kemudian dimasukkan ke wadah tertutup rapat. Sampel yang telah ditimbang diekstraksi dengan $3 \mathrm{~L}$ metanol pada suhu kamar selama 5 hari sambil sesekali diaduk. Setelah 5 hari sampel disaring dengan menggunakan kertas saring menghasilkan filtrat satu. Filtrat daun turi selanjutnya dievavorasi sehingga menghasilkan ekstrak seperti pasta. Pasta yang dihasilkan kemudian diencerkan menggunakan aquades sehingga diperoleh konsentrasi ekstrak sebesar $55 \%, 40 \%, 25 \%$ dan $10 \%$.

\section{Uji Fitokimia Secara Kualitatif Ekstrak Daun Turi}

Identifikasi senyawa kimia ekstrak daun turi (Harbone 1998)

a. Uji flavanoid sebanyak $2 \mathrm{~mL}$ sampel $(0,05 \% \mathrm{~b} / \mathrm{v})$ dilarutkan dalam $2 \mathrm{~mL}$ metanol, kemudian ditambahkan serbuk $\mathrm{Mg}$ dan $\mathrm{HCl}$ pekat sebanyak 5 tetes. Adanya senyawa flavanoid ditunjukkan dengan terbentuknya warna merah atau jingga.

b. Uji saponin sebanyak $2 \mathrm{~mL}$ sampel $( \pm 0,05 \% \mathrm{~b} / \mathrm{v})$ dilarutkan dalam aquades pada tabung reaksi ditambah 10 tetes $\mathrm{KOH}$ dan dipanaskan dalam penangas air $50{ }^{\circ} \mathrm{C}$ selama 5 menit, dikocok selama 15 menit. Jika terbentuk busa mantap setinggi $1 \mathrm{~cm}$ dan tetap stabil selama 15 menit menunjukkan adanya senyawa saponin.

c. Uji terpenoid sebanyak $2 \mathrm{~mL}$ sampel $( \pm 0,05 \%$ $\mathrm{b} / \mathrm{v})$ ditambah dengan pereaksi Liberman Burchard $1 \mathrm{~mL}$. Adanya senyawa terpenoid ditujukan dengan terbentuknya warna biru tua atau hijau kehitaman.

d. Uji stereoid sebanyak $2 \mathrm{~mL}$ sampel $( \pm 0,05 \% \mathrm{~b} / \mathrm{v})$ ditambah dengan pereaksi Liberman Burchard 1 $\mathrm{mL}$. Adanya senyawa steroid ditunjukkan dengan terbentuknya warna biru tua atau hijau kehitaman.

e. Uji tanin dilakukan melalui penambahan $\mathrm{FeCl} 3$ pada ektstrak daun turi. Senyawa tanin adalah senyawa yang bersifat polar karena adanya gugus $\mathrm{OH}$, ketika ditambahkan $\mathrm{FeCl}_{3} 10 \%$ akan terjadi perbahan warna seperti biru tua atau hijau kehitaman yang menandakan adanya senyawa tanin (Jones dan Kinghorn, 2006; Robinson, 1995).

Pembuatan Media Dasar dan Media Kultur Nutrient Agar sebanyak 5,6 gram dilarutkan dalam $200 \mathrm{~mL}$ aquadest. Media kemudian dihomogenkan dengan stirer diatas penangas air sampai mendidih. Media yang sudah homogen ini disterilkan dalam autoklaf pada suhu $121^{\circ} \mathrm{C}$ selama 15 menit, kemudian didinginkan sampai suhu \pm 45 $50^{\circ} \mathrm{C}$. Media dasar dan media pembenihan digunakan dalam pembuatan media pengujian sebagai lapisan dasar dan lapisan kedua.

\section{Regenerasi Bakteri}

Bakteri $K$. pneumoniae yang akan diujikan, terlebih dahulu harus diregenerasikan. Hal pertama yang dilakukan yaitu membuat media miring nutrient agar (NA). Media NA dituangkan kedalam tabung reaksi, kemudian diletakkan pada posisi miring dan didiamkan hingga agar memadat. Selanjutnya menggoreskan biakan dari stok bakteri ke agar miring nutrient agar (NA). kultur bakteri pada masingmasing agar miring diinkubasi pada suhu $37^{\circ} \mathrm{C}$ selama 18-24 jam.

\section{Suspensi Bakteri}

Suspensi bakteri dilakukan dengan cara bakteri uji yang telah diregenerasi diambil dengan jarum ose lalu disuspensikan ke dalam tabung reaksi berisi $5 \mathrm{~mL}$ larutan $\mathrm{NaCl}$ steril $0,9 \%$. Suspensi yang terbentuk disetarakan kekeruhannya dengan larutan standar Mc Farland No.1 yaitu 3 x $10^{8} \mathrm{CFU} / \mathrm{mL}$.

\section{Uji Efektivitas}

Media dibuat dengan media Muller Hilton Agar (MHA) sebanyak 18 gr dalam $500 \mathrm{~mL}$, kemudian disterilisasi menggunakan autoclave dan dituangkan sebanyak $20 \mathrm{~mL}$ ke dalam cawan petri. Setelah media padat, diinkubasi hingga 48 jam pada suhu $37^{\circ} \mathrm{C}$. Pengamatan dilakukan setelah $1 \times 24$ jam masa inkubasi. Zona bening merupakan petunjuk kepekaan bakteri terhadap antibiotik atau bahan antibakteri yang dinyatakan dengan lebar diameter zona hambat (Vandepitte, 2005). Diameter zona hambat diukur kemudian dikategorikan kekuatan daya antibakterinya berdasarkan penggolongan dengan membandingkan diameter zona bening yang terbentuk dengan standar diameter zona bening $<8 \mathrm{~mm}$ lemah, 8-12 mm kuat, dan $>12 \mathrm{~mm}$ sangat kuat (Vasanthakumari, 2009).

\section{Hasil dan Pembahasan}

\section{Hasil Uji Kualitatif Senyawa Metabolit Sekunder Ekstrak Methanol Daun Turi}

Hasil uji kualitatif senyawa metabolit sekunder ekstrak metanol daun turi meliputi uji saponin, terpenoid, tanin, steroid dan flavonoid pada tabel berikut. 
Tabel 1. Hasil Uji kualitatif Senyawa Metabolit Sekunder Ekstrak Daun Turi (S. grandiflora L.)

\begin{tabular}{cccc}
\hline No. & Nama Uji & Perubahan/ Warna yang Terbentuk & Hasil \\
\hline 1 & Saponin & Berbusa & Positif \\
2 & Terpenoid & Biru tua/hijau kehitaman & Positif \\
3 & Tanin & Hijau kehitaman & Positif \\
4 & Steroid & Hijau cerah & Negatif \\
5 & Flavonoid & Hijau kekuningan & Negatif \\
\hline
\end{tabular}

Ket: terbentuknya busa pada uji saponin dengan tinggi $1 \mathrm{~cm}$

\section{Hasil Uji Bakteri Ekstrak Methanol Daun Turi}

Aktivitas antibakteri ekstrak daun turi ditunjukkan dengan adanya zona hambatan/zona bening (clear zone) di sekeliling sumuran yang berisi ektrak daun turi dengan berbagai konsentrasi.
Diameter zona hambat diukur untuk mengetahui potensi aktivitas antibakteri tiap konsentrasi ektrak terhadap bakteri uji. Berdasarkan hasil penelitian terhadap pembentukan zona hambat diperoleh hasil seperti tertera pada Tabel 2.

Tabel 2. Diameter zona hambatan ekstrak daun turi (S. grandiflora L.) terhadap pertumbuhan bakteri Klebsiella pneumonia

\begin{tabular}{ccccccc}
\hline \multirow{2}{*}{ No. } & $\begin{array}{c}\text { Konsentrasi } \\
\text { Ektrak }\end{array}$ & \multicolumn{2}{c}{ Diameter Zona Hambat (mm) } & \multirow{2}{*}{ Rerata } & \multirow{2}{*}{ Kategori* } \\
\cline { 3 - 5 } & Ulangan 1 & Ulangan 2 & Ulangan 3 & & \\
\hline 1. & $10 \%$ & 6,5 & 7,1 & 8,1 & 7,2 & Lemah \\
2. & $25 \%$ & 14,5 & 16,0 & 12,6 & 14,4 & Sangat kuat \\
3. & $40 \%$ & 16,6 & 15,8 & 21,4 & 17,9 & Sangat kuat \\
4. & $55 \%$ & 19,3 & 23,1 & 25,2 & 22,5 & Sangat kuat \\
5. & Kontrol + & 39,2 & 32,2 & 36,9 & 36,6 & Sangat kuat \\
6. & Kontrol - & 0,0 & 0,0 & 0,0 & 0,0 & \\
\hline \multicolumn{2}{l}{ Keterangan: } & $*<8$ mm lemah, $8-12 \mathrm{~mm}$ kuat, $>12 \mathrm{~mm}$ sangat kuat &
\end{tabular}

\section{Pembahasan}

Penelitian yang telah dilakukan di Laboratorium Pendidikan Biologi di Fakultas Keguruan dan Ilmu Pendidikan Universitas Mataram bertujuan untuk mengetahui adanya aktivitas ekstrak daun turi ( $S$. grandoflora) terhadap pertumbuhan $K$. pneumoniae.

Penelitian ini menggunakan bahan uji daun turi putih ( $S$. grandiflora) yang telah diangin-anginkan di tempat yang terlindung dari cahaya matahari langsung dan di blender, kemudian di maserasi selama 5 hari menggunakan pelarut methanol karena dapat menarik komponen kimia yang bersifat polar. Proses penarikan zat aktif yang terkandung didalamnya dilakukan dengan metode maserasi, karena metode ini merupakan salah satu metode yang sederhana dan penarikan senyawa yang terkandung lebih efektif. Selain itu, bahan uji memiliki tekstur yang lunak dan komponen kimia yang tidak tahan pemanasan, metode maserasi tidak dipanaskan sehingga zat aktif dari bahan uji tidak terurai.

Uji daya hambat ekstrak daun Turi terhadap bakteri $K$. pneumoniae menggunakan metode difusi sumuran. Metode ini menggunakan media Muller Hilton Agar (MHA) karena merupakan medium yang baik sebagai tempat menguji aktivitas daya hambat bakteri gram positif maupun gram negatif. Dalam uji efektivitas diperoleh hasil melalui pengamatan yang dilakukan selama 1 x 24 jam masa inkubasi pada suhu $37^{\circ} \mathrm{C}$ dengan 3 kali pengulangan. Kontrol positif yang digunakan adalah antibiotik ciprofloxacin.

Penelitian ini dilakukan dengan menggunakan dalam 3 ulangan dimana setiap cawan dilubangi, masing-masing untuk 4 konsentrasi yang berbeda dan dua untuk kontrol negatif dan kontrol positif. Zona hambatan ekstrak metanol daun turi terhadap pertumbuhan $K$. pneumoniae yang ditandai dengan adanya lingkaran transparan mengelilingi sumuran tersebut yang disebabkan oleh adanya proses difusi dari ekstrak daun turi yang dapat menghambat pertumbuhan bakteri $K$. pneumoniae.

Pengukuran dilakukan dengan menggunakan kertas milimeter blok dan diperoleh diameter rata-rata pada konsentrasi $10 \%$ sebesar $17,6 \mathrm{~mm}, 25 \%$ sebesar $11,6 \mathrm{~mm}, 40 \%$ sebesar 10,4 mm dan konsentrasi $55 \%$ sebesar 20,2 mm, sedangkan pada kontrol negatif tidak memperlihatkan adanya zona hambat. Keempat konsentrasi ekstrak daun turi memperlihatkan terjadinya peningkatan diameter hambatan dengan adanya kenaikan konsentrasi. Hal ini disebabkan karena semakin tinggi konsentrasi semakin tinggi komponen senyawa kimia yang terkandung dalam daun turi sehingga memberikan daya hambat yang lebih besar terhadap pertumbuhan $K$. pneumoniae. Dwidjoseputro (2003) mengungkapkan semakin 
rendah konsentrasi dari antibiotik maka daya hambatnya akan semakin lemah sehingga zona yang terbentuk akan semakin kecil dan sebaliknya semakin tinggi konsentrasi antibiotik, maka semakin kuat daya hambatnya sehingga semakin besar zona bening yang terbentuk.

Berdasarkan Tabel 2, dapat diketahui bahwa zona hambat paling tinggi dihasilkan oleh konsentrasi ekstrak daun turi sebanyak 55\% dengan rata-rata 22,5 $\mathrm{mm}$, sedangkan rata-rata zona hambat paling rendah pada konsentrasi $10 \%$ yakni $7,2 \%$. Terbentuknya daerah zona hambat menunjukkan terjadinya penghambatan pertumbuhan koloni bakteri yang diduga akibat pengaruh senyawa bioaktif yang terdapat pada ekstrak daun turi. Hasil penelitian Padmalochana dan Rajan (2014) membuktikan bahwa ekstrak etanol daun turi memiliki aktivitas antimikroba pada semua mikroba uji, antara lain Escherichia coli, Pseudomonas aeruginosa, Staphylococcus aureus, Klebsiella pneumoniae, Bacillus subtilis, Candida sp, dan Klebsiella planticola. Daun turi mengandung zat aktif yang berperan sebagai antibakteri diantaranya saponin (Hariana, 2006), alkaloid, flavanoid, glikosida, tannin dan steroid (Arun et al., 2014; Reji \& Alphonse, 2013). Dimana senyawa-senyawa tersebut diduga merupakan senyawa yang berperan dalam menghambat pertumbuhan bakteri Klebsiella pneumoniae.

Vasanthakumari (2009) membagi zona jernih atau zona bening yang terbentuk menjadi 3 kelompok yaitu kategori sangat kuat bila zona hambat $>12 \mathrm{~mm}$, kuat 8-12 mm, dan lemah $<8 \mathrm{~mm}$. Berdasarkan uji aktivitas antibakteri ekstrak metanol daun turi terhadap bakteri $K$. pneumoniae diperoleh bahwa diameter zona hambat pada konsentrasi 55\%, 40\% dan $25 \%$ termasuk dalam kategori kuat, sedangkan zona hambat terendah konsentrasi $10 \%$ dengan kategori resisten.

Besarnya zona hambat yang dihasilkan dari keempat perlakuan tersebut disebabkan oleh kandungan bioaktif yang terdapat dalam ekstrak daun turi. Hal ini dapat dibuktikan pada pengujian senyawa metabolit sekunder yang menunjukkan hasil positif pada uji saponin, terpenoid dan tanin, Senyawa saponin apabila berinteraksi dengan bakteri maka senyawa tersebut akan mengganggu permeabilitas sel, saat tegangan permukaan terganggu, zat anti bakteri akan dapat dengan mudah masuk kedalam sel dan akan mengganggu metabolisme hingga akhirnya terjadilah kematian bakteri (Pratiwi, 2008). Hal tersebut diperkuat oleh Nuria, et al. (2009), bahwa mekanisme kerja saponin sebagai antibakteri adalah menurunkan tegangan permukaan sehingga mengakibatkan naiknya permeabilitas atau kebocoran sel dan mengakibatkan senyawa intraseluler akan keluar. Pernyataan Nuria, et al. (2009) diperkuat oleh Cavalieri, et al. (2005) bahwa senyawa ini berdifusi melalui membran luar dan dinding sel yang rentan, lalu mengikat membran sitoplasma dan mengganggu dan mengurangi kestabilan sel. Hal ini menyebabkan sitoplasma bocor keluar dari sel yang mengakibatkan kematian sel.

Mekanisme kerja senyawa terpenoid sebagai zat antibakteri diduga melibatkan kerusakan membran oleh senyawa lipofilik (Cowan, 1999). Terpenoid dapat bereaksi dengan porin (protein trasmembran) pada membran luar dinding sel bakteri, membentuk ikatan polimer yang kuat dan merusak porin, mengurangi permeabilitas dinding sel bakteri sehingga sel bakteri kekurangan nutrisi dan menyebabkan pertumbuhan bakteri terhambat dan mati (Rachmawati, 2011).

Mekanisme penghambatan tanin yaitu dengan cara dinding sel yang telah lisis akibat senyawa saponin dan flavonoid, sehingga menyebabkan senyawa tannin dapat dengan mudah masuk kedalam sel dan mengkoagulasi protoplasma sel mikroba. Senyawa tanin dapat berperan sebagai antibakteri karena dapat mengganggu sintesa peptidoglikan sehingga pembentukan dinding sel bakteri menjadi kurang sempurna. Mekanisme kerja tanin sebagai antibakteri berhubungan dengan target penyerangan tanin terhadap kerusakan polipeptida yang terdapat pada dinding sel bakteri sehingga mengganggu sintesa peptidoglikan yang menjadikan pembentukan dinding sel tidak sempurna dan mengakibatkan inaktivasi sel bakteri (Masduki, 1996).

Senyawa bioaktif yang terdapat pada $S$. grandiflora yang bersifat bakteriosidal yaitu senyawa yang dapat merusak pertahanan dan sel bakteri yang menyebabkan kerusakan sel dan pada akhirnya menyebabkan kematian pada bakteri yang diserang. Nikham dan Taty (2012) menjelaskan bahwa mekanisme kerja antimikroba adalah menghambat biosintesis dinding sel, meningkatkan permeabilitas membrane sel, dan mengganggu sintesis protein sel, sehingga menghambat pertumbuhan atau menyebabkan kematian sel bakteri. Umumnya, antimikroba yang mempengaruhi pembentukan dinding sel atau permebilitas membrane sel bekerja sebagai bakteriosidal, sedangkan yang mempengaruhi sintesis protein bekerja sebagai bakteriostatik.

Kerentanan $K$. pneumoniae karena perlakuan ekstrak daun $S$. grandiflora kemungkinan disebabkan oleh kerusakan sel bakteri tersebut karena hambatan sintesis dinding selnya. Hal ini diduga karena adanya kandungan senyawa kimia seperti saponin terpenoid dan tannin (Tabel 1), K.pneumoniae merupakan bakteri gram negatif. Dinding sel bakteri gram negatif terdiri atas peptidoglikan yang tipis. Dinding sel bakteri gram negatif sebagian besar tersusun oleh membran lipid di bagian terluar membran, sehingga melapisi peptidoglikan yang terletak di bawah membran lipid tersebut. Proses perakitan dinding sel bakteri diawali dengan pembentukan rantai peptida yang akan membentuk jembatan silang peptida yang menggabungkan rantai glikan dari peptidoglikan pada rantai yang lain sehingga menyebabkan dinding sel terakit sempurna. Jika ada kerusakan pada dinding sel 
atau ada hambatan dalam pembentukannya maka akan terjadi lisis pada sel bakteri sehingga bakteri segera kehilangan kemampuan membentuk koloni dan diikuti dengan kematian sel bakteri.

Pada $K$. pneumoniae pemberian antimikroba dapat menghambat perakitan dinding sel dan mengakibatkan penggabungan rantai glikan tidak terhubung silang ke dalam peptidoglikan dinding sel menyebabkan suatu struktur menjadi lemah dan menyebabkan kematian bakteri. (Morin dan Gorman, 1995). Setiap senyawa yang menghalangi tahap apapun dalam sintesis peptidoglikan akan menyebabkan dinding sel bakteri diperlemah dan sel menjadi lisis (Jawetz et al., 2001). Lisisnya sel bakteri tersebut dikarenakan tidak berfungsinya lagi dinding sel yang mempertahankan bentuk dan melindungi bakteri. Tanpa dinding sel, bakteri tidak dapat bertahan terhadap pengaruh luar dan segera mati (Ajizah et al., 2007).

\section{Kesimpulan}

Hasil uji fitokimia secara kualitatif dalam studi ini menunjukkan bahwa ekstrak metanol daun turi mengandung senyawa metabolit sekunder seperti tannin, saponin, dan terpenoid. Keberadaan kandungan senyawa metabolit sekunder di atas memberikan kemampuan daya hambat yang kuat pada konsentrasi 55\%, 40\% dan 25\% dari ekstrak methanol dari terhadap pertumbuhan bakteri Klebsiella pneumoniae.

\section{Ucapan Terima Kasih}

Penulis berterimakasih kepada FKIP Universitas Mataram atas bantuan beasiswa penelitian dan rekan- rekan mahasiswa magister pendidikan IPA Universitas Mataram yang telah banyak membantu dalam proses penelitian.

\section{Daftar Pustaka}

Ajizah, A., Thihana, Mirhanuddin (2007). Potensi Ekstrak Kayu Ulin (Eusideroxylon zwageri TetB) dalam Menghambat Pertumbuhan Bakteri Staphylococcus aureus Secara In Vitro. Bioscientiae. 4 (1): 37-42. DOI: (https://ppjp.ulm.ac.id/journals/index.php/bios cientiae/article/view/161).

Amaranti, W., Inur, T. \& Aldi B. R. (2017). Uji Kandungan Saponin pada Daun, Tangkai Daun dan Biji Tanaman Turi (Sesbania grandiflora). Politeknik Tegal: Seminar Nasional 2nd IPTEK Terapan (SENIT). DOI: (http://ejournal.poltektegal.ac.id/index.php/SE NIT2017/article/view/565).

Anderson, K.F., Lonsway, D.R. \& Rasheed, J.K., (2007). Evaluation of methods to identify the
Klebsiella pneumoniae carbapenemase in Enterobacteriaceae. J Clin Microbiol, 45, pp.2723-5. DOI: (https://www.ncbi.nlm.nih.gov/pubmed/17581 941).

Arun, A., Karthikeyan, P., Sagadevan, P. A., Umamaheswari, R.A. \& Rex-Peo, R. (2014). Phytochemical Screening of Sesbania grandifora Linn. Int.J. Biosci. Nanosci. 1 (2): 33-36.

DOI: (https://www.semanticscholar.org/paper/Phyt ochemical-screening-of-Sesbania-grandifloraArun/2f8f788590f173cce00b81a6d7819c7866 2ad6ae\#paper-header).

Arunabha, M. \& Satish, N. (2015). Study the Immunomodulatory Effects of Combined Extracts of Sesbania grandiflora Flowers and Cocculus hirsutus Leaves on The Circulating Antibody Response. Am. J. Phytomed. Clin. Ther. 3 (3): 199-208. DOI: (https://www.imedpub.com/abstract/studythe-immunomodulatory-effectsofrncombined-extracts-of-sesbaniagrandiflorarnflowers-and-cocculus-hirsutusleaves-onrnthe-circulating-antibody-response10360.html).

Avalaskar A.N., Itankar P.R., Joshi V.S., Agrawal M. \& Vyas J. (2011). Phytochemical and TLC Studies of Ethanolic Extract of Sesbania grandiflora (Fabaceae). Int.J. Pharm.Tech. Res. 3 (3): 1346-1349. DOI: (http://www.sphinxsai.com/Vol.3No.3/pharm/ pdf/).

Bangun, A. (2012). Ensiklopedia Tanaman Obat Indonesia. Bandung: IPH

Beesley, T., Gascoyne, N. \& KnottHunziker, V., (1983). The inhibition of class C $\beta$-lactamases by boronic acids. Biochem J, 209, pp.229-33. DOI:

(https://www.ncbi.nlm.nih.gov/pmc/articles/P MC1154076/).

Cavalieri, S.J., Rankin, I.D., Harbeck, R.J., Sautter, R.S., McCarter, Y.S., Sharp, S.E., Ortez, J.H. and Spiegel, C.A. (2005). Manual of Antimicrobial Susceptibility Testing. USA: American Society for Microbiology.

Cowan, M.M. (1999). Plant Products as Antimicrobial Agents. Clinical Microbiology Review. 12(4): 564-582.

DOI: (https://www.ncbi.nlm.nih.gov/pubmed/10515 903). 
Dwidjoseputro, D. (2003). Dasar-Dasar Mikrobiologi. Djambatan. Jakarta.

Harborne, J. B. (1998). Phytochemical Methods: A Guide to Modern Techniques of Plant Analysis. Edisi ke-3. Chapman and Hall, New York. Halaman 4-6, 30-31, 60-61, 90-92, 108110, 132-133, dan 203-205. DOI: https://www.springer.com/gp/book/97804125 $\underline{72609}$

Hariana, A.H. (2006). Tumbuhan Obat dan Khasiatnya seri 3. Jakarta: Penebar Swadaya.

Jawetz, M. \& Adelberg, E. (2005). Mikrobiologi Kedokteran. Jakarta: Buku Kedokteran ECG.

Jones, W.P. \& Kinghorn, A.D. (2006). Extraction of Plant Secondary Metabolites. In: Sharker, S.D. Latif Z., Gray A.L, eds. Natural Product Isolation. 2 nd edition. New Jersey: Humana Press.

Lestari, P. (2016). Studi Tanaman Khas Sumatera Utara yang Berkhasiat sebagai Obat. Akademi Farmasi Yayasan Tenaga Pembangunan Arjuna, Sumatera Utara.

Masduki (1996). Efek Antibakteri Ekstrak Biji Pinang (Areca catechu) terhadap S. aureus dan E. coli. Cermin Dunia Kedokteran, Jakarta.

Morin R.B. \& M. Gorman (1995). Kimia dan Biologi Antibiotik $\beta$-Lactam (Chemistry and Biology of b-Lactam Antibiotics). Edisi III. Diterjemahkan oleh Mulyani S. Semarang: IKIP Semarang Press.

Nikham \& Taty E.B. (2012). Uji Baku Antibakteri dari Buah Mahkota Dewa (Phaleria Macrocarpa (Scheff) Boerl) Hasil Iradiasi Gamma dan Antibiotik Terhadap Bakteri Patogen. Dalam: Prosiding Pertemuan Ilmiah Ilmu.

Nuria, M. C., Faizatun, A. \& Sumantri (2009). Uji Aktivitas Antibakteri Ekstrak Etanol Daun Jarak Pagar (Jatropha Curcas L) Terhadap Bakteri Staphylococcus Aureus ATCC 25923, Escherichia Coli ATCC, dan Salmonella Typhi ATCC 1408. Mediagro. 5(2):26-37. DOI: (https://media.neliti.com/media/publications/1 49782-ID-none.pdf).

Padmalochana, K. \& Rajan, D. M. S. (2014). Antimicrobial Activity of Aqueous, Ethanol and Acetone Extracts of Sesbania grandifora Leaves and Its Phytochemical Characterization. Int. J. of Pharma Sciences and Research. 5(12): 957-962. DOI:
(http://www.ijpsr.info/docs/IJPSR14-05-12035.pdf).

Panda, C., U.S. Mishra, S. Mahapatra, G. \& Panigrahi (2013). Free Radical Scavenging Activity and Phenolic Content Estimation of Glinus oppositifolius and Sesbania grandiflora. Int. J. Pharm. 3(4): 722-727. DOI: (http://pharmascholars.com/abstractview/freeradical-scavenging-activity-and-phenoliccontent-estimation-of-glinus-oppositifoliusand-sesbania-grandiflora).

Pratiwi, S.T. (2008). Mikrobiologi Farmasi. Jakarta: Erlangga.

Rachmawati, F., Nuria M. C. \& Sumantri (2011). Uji Aktivitas Antibakteri Fraksi Kloroform Ektrak Etanol Pegagan (Centella asiantica (L) Urb) serta Identifikasi Senyawa Aktifnya. Semarang: Universitas Wahid. DOI: (https://scholar.google.co.id/citations?user=n8 ksTikAAAAJ\&hl=id).

Reji, A.F. \& Alphonse, R.N. (2013). Phytochemical Study on Sesbania grandiflora. J. Chem. Pharm. Res. 5(2): 196-201. DOI: (https://www.researchgate.net/publication/281 718054_Phytochemical_study_on_Sesbania grandiflora).

Robinson, T. (1995). Kandungan Organik Tumbuhan Tingkat Tinggi. ITB: Bandung.

Sarathbabu, R.V.T. Ramani, B.K. Rao, and S. Panda. (2012). Antibiotic Susceptibility Pattern of Klebsiella pneumoniae Isolated from Sputum, Urine and Pus Samples. IOSRJPBS. 1(2): 0409. DOI: (http://iosrjournals.org/iosrjpbs/papers/vol1-issue2/I0120409.pdf).

Sjoekoer, D.M., Roetiningsih \& Sinarto, S. (2003). Bakteriologi Medik. Jakarta: Banyumedika.

Vandepitte, S. (2005). Prosedur Laboratorium Dasar untuk Bakteriologis Klinis. Edisi 2. Buku Kedokteran EGC, Jakarta. Vandepitte, S. 2005. Prosedur Laboratorium Dasar untuk Bakteriologis Klinis. Edisi 2. Buku Kedokteran EGC, Jakarta.

Vasanthakumari, R. (2009). Practical Microbiology. New Delhi: BI Publications Pvt Ltd.

Vinothini, K., Devi, M.S., Shalini, V., Sekar, S., Semwal, R.B. and Arjun, P. (2017). In Vitro Micropropagation, Total Phenolic Content and Comparative Antioxidant Activity of Different Extracts of Sesbania grandiflora (L.) Pers. Curr. Sci. 113 (6): 1142-1147. DOI: 
Huurun Iien et al. (2020). Jurnal Biologi Tropis, 20 (2): 219 - 226 DOI: http://dx.doi.org/10.29303/jbt.v20i2.1790

(https://www.researchgate.net/publication/320 057976_In_vitro micropropagation total phe nolic content and comparative antioxidant activity_of_different_extracts_of_Sesbania_gr andiflora_L_Pers). 